\title{
Pengaruh Investasi Dan Inflasi Terhadap Jumlah Penduduk Miskin di Kabupaten Jember Tahun 2000-2015
}

\author{
(Effect of Inflation on Total Investment and Poor People in the District Jember \\ Year 2000-2015)
}

\author{
Abdul Latif Hamzah, Anifatul Hanim*, Herman Cahyo \\ Jurusan Ilmu Ekonomi dan Studi Pembangunan, Fakultas Ekonomi dan Bisnis, Universitas Jember (UNEJ) \\ Jln. Kalimantan 37, Jember 68121 \\ E-mail: hanim.feb@unej.ac.id
}

\begin{abstract}
Abstrak
Kondisi di Kabupaten Jember dari tahun ke tahun pertumbuhan ekonominya cukup tinggi, tetapi tingkat kemiskinannya sangat tinggi juga. Penelitian ini bertujuan untuk mengetahui pengaruh investasi dan inflasi terhadap jumlah penduduk miskin dikabupaten Jember tahun 2000-2015. Metode yang digunakan dalam penelitian ini adalah regresi linier berganda. Data yang digunakan adalah data sekunder yang terbentuk dalam runtut waktu (time series). Data yang digunakan meliputi investasi, inflasi di kabupaten Jember selama 16 tahun yaitu tahun 2000-2015. Berdasarkan hasil penelitian, dapat diketahui bahwa variabel investasi tidak berpengaruh signifikan terhadap jumlah penduduk miskin di Jember, sedangkan Inflasi berpengaruh signifikan terhadap jumlah penduduk miskin di Jember.
\end{abstract}

Kata kunci: investasi, inflasi dan jumlah penduduk miskin.

Abstract

Conditions in Jember Regency from year to year economic growth is quite high, but the poverty level is very high as well. This study aims to determine the effect of investment and inflation on the number of poor people in the district of Jember in 20002015. The method used in this research is multiple linear regression. The data used are secondary data formed in time series, the data used include investment, inflation in Jember district for 16 years in the year 2000-2015. Based on the results of the research, it can be seen that investment variables do not significantly affect the number of poor people in Jember, while Inflation has a significant effect on the number of poor people in Jember.

Keywords: total investment, inflation, and poor people.

\section{Pendahuluan}

Studi ekonomi umumnya menyatakan bahwa pengurangan kemiskinan bertalian erat dengan pertumbuhan ekonomi. Secara prinsip, pertumbuhan ekonomi merupakan persyaratan pertama dari pengentasan kemiskinan, sedangkan yang kedua adalah menjamin bahwa pertumbuhan tersebut adalah propoor (Kraay, 2006). Namun pertumbuhan penduduk dikhawatirkan akan menimbulkan efek yang buruk terhadap pertumbuhan ekonomi. Pertumbuhan penduduk yang cepat mendorong timbulnya masalah keterbelakangan dan membuat prospek pembangunan menjadi semakin jauh (Todaro 2000).

Dampak pertumbuhan ekonomi secara teori mampu mengurangi kemiskinan akan tetapi pertumbuhan bukannlah jaminan penuntasan masalah kemiskinan. Pertumbuhan yang tinggi belum tentu menjamin tingkat kemiskinan akan menurun. Bahkan pertumbuhan bisa jadi tidak ada kaitannya dengan penurunan angka kemiskinan.

Salah satu tujuan pembangunan nasional adalah meningkatkan kinerja pembangunan perekonomian agar mampu menciptakan lapangan kerja dan menata kehidupan yang layak bagi seluruh rakyat yang pada gilirannya akan mewujudkan kesejahteraan penduduk di Indonesia. Salah satu sasaran pembangunan adalah menurunkan jumlah penduduk miskin. Kemiskinan merupakan salah satu penyakit dalam ekonomi, sehingga harus disembuhkan atau dikurangi (Nasir, Muh, Saichudin dan Maulizar; 2008).

\footnotetext{
* Corresponding author
}

Menurut teori pembangunan ekonomi, penduduk memiliki 2 (dua) potensi yang kontradiktif yaitu: di satu sisi penduduk dapat menjadi beban bagi proses pembangunan, tetapi di sisi lain penduduk dapat menjadi modal pembangunan. Penduduk berjumlah besar dengan kualitas yang rendah merupakan beban bagi pembangunan karena

Kabupaten Jember merupakan daerah yang masuk dalam urutan pertama terkait angka kemiskinan di Jawa Timur tahun 2008. Jumlah penduduk miskin di Kabupaten Jember, mencapai 237.700 RTM (Rumah Tangga Miskin). Jumlah tersebut ternyata banyak, jika dibandingkan dengan 38 Kabupaten lain di Jawa Timur. Penduduk miskin adalah pihak yang memiliki pendapatan rata-rata dan pengeluaran per kapita per bulan di bawah garis kemiskinan, untuk Kabupaten Jember yaitu di bawah Rp 132.240/bulan (Badan Pusat Statistik Provinsi Jawa Timur, 2009). Badan Pusat Statistik (BPS) mengelompokkan kemiskinan menjadi tiga kelompok yaitu, sangat miskin, miskin, dan hampir miskin.

Usaha untuk mengurangi kemiskinan yang menjadi masalah di Jember, pemerintah mempunyai peranan penting dalam pengembangan investasi nasional: baik yang dilakukan oleh negara melalui investasi pemerintah, maupun investasi yang dilakukan oleh swasta. Penyelengaraan investasi atau penanaman modal di Jember hanya bisa tercapai apabila faktor-faktor yang menghambat iklim penanaman modal dapat diatasi, antara lain melalui perbaikan koordinasi antara instansi pemerintah pusat dan daerah. Penciptaan birokrasi yang efisien kepastian hukum dibidang penanaman modal, 
ketenagakerjaan dan keamanan usaha. Dengan adanya perbaikan berbagai faktor tersebut, diharapkan penanaman modal akan membaik secara signifikansi (Aprilianti, 2014).

Tujuan dari penelitian ini adalah Menganalisa seberapa besar pengaruh variabel investasi terhadap jumlah penduduk miskin di Kabupaten Jember, dan Menganalisa seberapa besar pengaruh variabel inflasi terhadap jumlah penduduk miskin di Kabupaten Jember.

Menurut Smith, akumulasi modal menerapkan syarat utama dalam pembangunan ekonomi yaitu bagaimana kemampuan manusia untuk lebih banyak menabung dan menanamkan modalnya. Tujuan Pembangunan ekonomi adalah membangun peralatan modal dengan skala yang cukup untuk meningkatkan produktivitas. Dengan meningkatkan produktivitas suatu perekonomian, maka akan terjadi penambahan tenaga kerja yang dipergunakan untuk proses produksi, sehingga kesempatan kerja juga akan meningkat (Lestari, 2011:44).

Menurut teori keynes, inflasi terjadi karena suatu masyarakat ingin hidup di luar batas kemampuan ekonominya. Proses inflasi menurut pandangan ini tidak lain adalah proses perebutan bagian rezeki di antara kelompok-kelompok sosial yang menginginkan bagian yang lebih besar daripada yang bisa disediakan oleh masyarakat tersebut. Proses perebutan ini akhirnya diterjemahkan menjadi keadaan dimana permintaan masyarakat akan barang-barang selalu melebihi jumlah barang-barang yang tersedia (timbul apa yang disebut dengan inflationary gap).

Hipotesis adalah teori sementara yang kebenarannya masih perlu diuji setelah peneliti mendalami permasalahan penelitiannya dengan seksama serta menetapkan anggapan dasar. Berdasarkan studi empiris penelitian yang pernah dilakukan dibidang ini, maka akan diajukan hipotesis sebagai berikut:

1. Diduga variabel investasi berpengaruh negatif terhadap jumlah penduduk miskin di Kabupaten Jember;

2. Diduga variabel inflasi berpengaruh positif terhadap jumlah penduduk miskin di Kabupaten Jember.

\section{Metode}

\section{Rancangan atau Design Penelitian}

Jenis penelitian ini adalah penelitian explanatori (Explanator Research). Penelitian explanatori merupakan penelitian yang menjelaskan hubungan kausal antara variabel penelitian dengan pengujian hipotesa. Di dalam penelitian explanatori, pendekatan yang di pakai dalam penelitian ini adalah metode suvey, yaitu penelitian yang dilakukan untuk memperoleh fakta-fakta mengenai fenomena yang ada di dalam obyek penelitian dan mencari keterangan secara aktual dan sistematis Effendi (Ed 1995).

\section{Jenis dan Sumber Data}

Jenis data yang digunakan dalam penelitian ini adalah data sekunder yang terbentuk dalam runtun waktu (time series). Data yang digunakan meliputi: investasi, inflasi dan jumlah penduduk miskin pada tahun 2000-2015. Penelitian ini tidak meneliti objek secara langsung untuk memperoleh data, melainkan mempergunakan data yang sudah tersedia. Sumber data dalam penelitian ini diperoleh dari dinas kependudukan dan tenaga kerja, biro atau keuangan Jember, dinas perindustrian dan perdagangan, badan pusat statistik, maupun instansi-instansi lainnya.

\section{Metode Analisis Data}

Penelitian ini menggunakan alat analisis dan metode dalam menjawab pertanyaan yang timbul dari rumusan masalah. Alat analisis tersebut yaitu analisis regresi linear berganda dan merupakan model analisis yang dipilih karena untuk mengetahui besarnya pengaruh dari perubahan suatu variabel dengan variabel lainnya yang ada di dalam. Analisis tersebut menentukan suatu persamaan yang menaksir sifat hubungan fungsional diantara variabel yang akan diteliti.

Uji statistik terdiri dari uji pengaruh secara bersama-sama (uji F), uji secara parsial (uji t), dan koefisien determinasi $\left(\mathrm{R}^{2}\right)$. Untuk memperjelas dan memperkuat pengaruh dari hasil analisis regresi yang diperoleh maka digunakan uji asumsi klasik. Uji asumsi klasik terdiri atas normalitas, linieritas, multikolineritas, heteroskedastisitas, dan autokorelasi.

\section{Hasil dan Pembahasan}

\section{Hasil}

Untuk mengetahui pengaruh investas dan inflasi terhadap jumlah penduduk miskin di Kabupaten Jember periode tahun 2000-2015 digunakan analisis regresi linear berganda Data dianalisis dengan menggunakan metode analisis regresi linear berganda (Gujarati, 2010) dan diolah dengan menggunakan software eviews dengan metode analisis sebagai berikut:

$$
\mathrm{Yt}=\alpha+\beta 1 \mathrm{X} 1+\beta 2 \mathrm{X} 2+\mathrm{et} \ldots
$$

Dimana,

$$
\begin{array}{ll}
\mathrm{Y} & =\text { JPM di Kabupaten Jember } \\
\beta 1 \mathrm{X} 1 & =\text { Investasi di Kabupaten Jember } \\
\beta 2 \mathrm{X} 2 & =\text { Inflasi di Kabupaten Jember } \\
\mathrm{t} & =\text { Waktu Tahun }(2000-2015) \\
\alpha & =\text { Konstanta } \\
\mathrm{e} & =\text { Standar Error }
\end{array}
$$

Hasil Analisis Regresi

\begin{tabular}{ccccc}
\hline Variable & Coefficient & Std Error & t-Stat & Prob. \\
C & 311.1198 & 335.4653 & 0.927428 & 0.3706 \\
INV & 15852.05 & $5838 . .296$ & 2.715184 & 0.0177 \\
INF & 17612.6 & 5246.71 & 3.288946 & 0.0059 \\
\hline
\end{tabular}

Nilai konstanta sebesar 172612,6 menunjukkan bahwa hubungan, variabel investasi dan inflasi konstan, maka jumlah penduduk miskin di Jember adalah sebesar 172612,6 jiwa/tahun.

Koefisien regresi variabel Investasi sebesar 311,1198 yang berarti bahwa setiap kenaikan investasi sebesar Rp 1.000.000/tahun, maka akan meningkatkan jumlah penduduk miskin di Jember sebesar 311,12 jiwa/tahun

Koefisien regresi variabel inflasi (INF) sebesar 15852,049 yang berarti bahwa setiap kenaikan inflasi sebesar 1\%/tahun, maka akan meningkatkan jumlah penduduk miskin di kabupaten Jember sebesar 15852,05 jiwa/tahun.

\section{Hasil Uji F}

Untuk menguji pengaruh secara serempak dari seluruh variable bebas terhadap variabel terhadap variabel terikat 
digunakan uji $\mathrm{F}$. hasil analisis table 4.3 nilai probabilitas $\mathrm{F}$ hitung $(0.000000)<(\alpha=0.05)$, berarti seluruh variabel investasi dan inflasi secara serentak berpengaruh terhadap signifikan terhadap jumlah penduduk miskin Kabupaten Jember

\section{Hasil Uji T}

Hasil estimasi dalam investasi menunjukkan bahwa p-value 0.3706 Dengan demikian, p-value $0.3706>(\alpha=0.05)$, sehingga Ho diterima Ha ditolak. Berdasarkan estimasi tersebut, diketahui bahwa investas berpengaruh tidak signifikan terhadap jumlah penduduk miskin di Kabupaten Jember.

Hasil estimasi dalam inflasi menunjukkan bahwa p-value 0.0177 Dengan demikian, p-value $0.0177<(\alpha=0.05)$, sehingga Ho ditolak Ha diterima. Berdasarkan estimasi tersebut, diketahui bahwa inflasi berpengaruh signifikan terhadap jumlah penduduk miskin di Kabupaten Jember.

\section{Adjusted R-squared}

Dari hasil analisis diatas nilai adjusted R-squared sebesar 0.270615 , artinya total variasi variabel terikat jumlah penduduk miskin mampu dijelaskan oleh variabel invetasi sebesar $27.06 \%$ sedangkan sisanya sebesar $72.94 \%$ dijelaskan variabel lain diluar model.

\section{Hasil Uji Normalitas}

\begin{tabular}{rr}
\hline Jarque-Bera & 0.863893 \\
Probability & 0.649244 \\
\hline
\end{tabular}

Berdasarkan gambar di atas probabilitas Jorque-Berra adalah sebesar 0.8639893. Oleh karena probabilitas Jarque-Berra $>\alpha$ (0.05) maka dapat dikatakan bahwa variabel pengganggu berdistribusi normal.

Hasil Uji Multikolinieritas

\begin{tabular}{cccc}
\hline & JPM & INV & INF \\
\hline JPM & 1.000000 & 0.096887 & 0.571001 \\
INV & 0.096887 & 1.000000 & -0.182467 \\
INF & 0.571001 & -0.182467 & 1.000000 \\
\hline
\end{tabular}

Berdasarkan hasil pengujian pada Tabel diatas menunjukkan bahwa secara umum multikoliniearitas dapat dideteksi dari ada tidaknya hubungan yang signifikan antar variabel bebas. Caranya dengan membandingkan korelasi (r) parsial variabel jumlah penduduk miskin, investasi dan inflasi apakah $>$ atau $<$ dari korelasi regresi (R). Korelasi $\mathrm{R}$ adalah akar dari $\mathrm{R}^{2}$ atau jika $\mathrm{r}<0.8$ berarti tidak terjadi multikoliniearitas.

\section{Uji Autokorelasi}

\begin{tabular}{cccc}
\hline Obs*F-statistik & 1.073653 & Prob.F(2.15) & 0.3750 \\
Obs*R-squared & 2.613288 & Prob. Chi-Square(2) & 0.2707
\end{tabular}

Berdasarkan tabel di atas digunakan probabilitas Chi-Square adalah 0.2707. Oleh karena itu probabilitas Chi-Square $0.2707>\alpha(0.05)$ maka dapat dikatakan dalam model tersebut.

\section{Uji Heterokedastisitas}

\begin{tabular}{lclc}
\hline Obs*R-squared & 1.979563 & $\begin{array}{l}\text { Prob. Chi- } \\
\text { Square(2) }\end{array}$ & 0.3717 \\
$\begin{array}{l}\text { Scaled } \\
\text { SS }\end{array}$ & explained 1.590512 & $\begin{array}{l}\text { Prob. Chi- } \\
\text { Square(2) }\end{array}$ & 0.4515 \\
\hline
\end{tabular}

Berdasarkan tabel di atas digunakan probabilitas Chi-Square adalah 0.3717. Oleh karena itu probabilitas Chi-Square $0.3717>\alpha(0.05)$ maka dapat dikatakan dalam model tersebut bersifat homokedastisitas.

\section{Pembahasan}

Peneltian ini bersifat explanatory yaitu peneltian yang bertujuan untuk menjelaskan ada atau tidaknya hubungan antar variabel independen yaitu investasi (INV), inflasi (INF) terhadap variabel dependen jumlah penduduk miskin (JPM). Penelitian ini dilakukan di Kabupaten Jember, periode tahun 2000 sampai dengan tahun 2015.

Berdasarkan hasil pengujian analisis regresi menunjukkan hasil penelitian ini secara serentak memiliki pengaruh terhadap jumlah penduduk miskin di Kabupaten Jember tahun 2000-2015 dan secara bersama-sama mampu menjelaskan variabel terikat di dalam model.

Hasil estimasi regresi linier berganda menunjukkan bahwa variabel Investasi (INV) tidak berpengaruh secara signifikan dan memilki koefisien positif terhadap jumlah penduduk miskin (JPM) di Kabupaten Jember 2000-2015. Artinya dengan semakin meningkat investasi yang ditanamkan dikabupaten jember maka akan mengakibatkan meningkatnya jumlah penduduk miskin, begitu pula sebaliknya bila terjadi penurunan jumlah investasi maka tidak akan mengakibatkan menurunnya jumlah penduduk miskin.

Hasil estimasi regresi linier berganda menunjukkan bahwa variabel inflasi (INF) berpengaruh secara signifikan dan memilki koefisien positif terhadap jumlah penduduk miskin (JPM) di Kabupaten Jember periode 2000-2015. Artinya dengan semakin meningkat inflasi yang terjadi tiap tahun dikabupaten jember maka akan mengakibatkan meningkatnya jumlah penduduk miskin, begitu pula sebaliknya bila terjadi penurunan inflasi yang terjadi tiap tahun maka akan mengakibatkan menurunnya jumlah penduduk miskin.

Teori kemiskinan neo-liberal, faktor kemiskinan disebabkan oleh lemahnya pendapatan yang dimiliki oleh setiap individu. Menurut paradigma neo-libera, perluasan pasar dan peningkatan pendapatan merupakan kunci dalam menyelesaikan masalah. Adanya pendapatan yang tinggi dapat mempengaruhi kesejahteraan masyarakat dalam suatu wilayah, sebaliknya pendapatan semakin menurun yang disebabkan oleh produktifitas menurun dari waktu ke waktu maka akan mengurangi kesejahteraan masyarakat dan angka kemiskinan meningkat. Investasi adalah penempatan sejumlah dana dengan harapan dapat memelihara, menaikkan nilai, atau memberikan return yang positif (Sutha, 2000). Menurut Sukirno (2000). kegiatan investasi yang dilakukan oleh masyarakat secara terus menerus akan meningkatkan kegiatan ekonomi dan kesempatan kerja, meningkatkan pendapatan nasional dan meningkatkan taraf kemakmuran masyarakat. 
Pengaruh variabel investasi (INV) terhadap variabel jumlah penduduk miskin (JPM) yaitu positif dan tidak signifikan. Berpengaruh tidak signifikan karena variabel investasi merupakan variabel utama dalam usaha pemerintah untuk mengurangi jumlah penduduk miskin di Kabupaten Jember, Namun usaha ini belum mampu untuk menekan angka kemiskinan yang dihadapi dan realitanya

Investasi ini justru menambah jumlah penduduk miskin. Hal ini dikarenakan manfaat investasi tidak dapat dirasakan secara langsung dan merata untuk pemenuhan kesejahteraan masyarakat, serta butuh proses bertahun-tahun untuk merasakan manfaatnya. Hasil penelitian ini sesuai dengan hasil penelitian yang dikemukakan Chairul Nizar, Abu Bakar Hamzah, Sofyan Syahnur (2013) yang menyatakan bahwa investasi berpengaruh positif dan tidak signifikan terhadap kemiskinan, namun hasil penelitian ini tidak sesuai dengan teori Smith dan hipotesis yang sudah ada, karena dengan adanya investasi diharapkan dapat meningkatkan kesejahteraan masyarakat melalui distribusi kesempatan kerja dan meningkatkan pendapatan masyarakat. Inflasi merupakan kenaikan harga-harga umum secara berkelanjutan. Umum berarti kenaikan harga tidak hanya terjadi pada satu jenis barang saja, tapi kenaikan harga barang itu meliputi barang yang dikonsumsikan oleh masyarakat dan akan mempengaruhi harga barang lain dipasar. Berkelanjutan berarti kenaikan harga hanya terjadi sesaat saja (Suparmono,2004).

Pengaruh variabel inflasi (INF) terhadap variabel jumlah penduduk miskin (JPM) yaitu positif dan signifikan. Berpengaruh signifikan karena inflasi merupakan salah satu faktor yang dapat meningkatkan jumlah penduduk miskin, dikarenakan fluktuasi/lonjakan harga yang drastis dan tidak stabil sehingga daya beli masyarakat berkurang dan konsumsi terhadap barang dan jasa menurun dan pada akhirnya kesejahteran menurun serta jumlah penduduk miskin meningkat. Hasil penelitian ini sesuai dengan penelitian yang dikemukakan oleh Tito (2015) yang menyatakan bahwa inflasi berpengaruh positif terhadap kemiskinan dan hasil penelitian ini juga sesuai dengan teori yang dikemukan Keynes yang dikutip dalam Sukirno (2006). Dampak inflasi terhadap ekonomi masyarakat di Jember dapat menurunkan daya beli masyarakat yang menyebabkan penerimaan barang dan jasa menurun. karena penerimaan barang dan jasa menurun akan diimbangi dengan menurunnya sektor riil sehingga pertumbuhan ekonomi juga menurun sehingga jumlah penduduk miskin meningkat dan angka kemiskinan meningkat.

\section{Simpulan}

Berdasarkan analisis data dan pembahasan penelitian tidak terdapat pengaruh dan terdapat pengaruh inflasi terhadap jumlah penduduk miskin di Kabupaten Jember. Maka dapat disimpulkan sebagai beriku :1). Investasi (INV) berpengaruh positif dan tidak signifikan terhadap jumlah penduduk miskin
(JPM) di Kabupaten Jember; 2). Variabel inflasi (INF) berpengaruh positif dan signifikan terhadap jumlah penduduk miskin (JPM) di Kabupaten Jember..

\section{Referensi}

Aprilianti, F. 2014. "Analisis Pengaruh Investasi, Tenaga Kerja, Pengeluaran Publik dan Ekspor Terhadap Pertumbuhan Ekonomi Jawa Timur". Jember: Universitas Jember.

Arikunto. 2006. "Prosedur Penelitian Suatu Pendekatan Praktek". Jakarta : Rineka Cipta.

Badan Pusat Statistik. 2000. Jember Dalam Angka 2000-2015: Badan Pusat Statistik.

Criswardani Suryawati, 2005. "Memahami Kemiskinan Secara Multidimensional”. Diakses tanggal 11 November 2009.

Djannata, Azzi, A. 2011. “Analisis Program-Program Penanggulangan Kemiskinan Menuru SKPD (Satuan Kerja Perangkat Daerah) Di Kota Semarang Dengan Metode AHP(Analisis Hierarki Proses)". Skripsi. Semarang.

Dumairy, 1996, "Perekonomian Indonesia”, Erlangga,Jakarta.

Febriana, Eny. 2010. Strategi untuk Peningkatan Pendapatan Rumah Tangga Petani Miskin di Perdesaan: Studi Kasus dalam Rumah Tangga Petani Miskin di Desa Cisaat Kecamatan Cicurung Kabupaten Sukabumi. Universitas Indonesia

Gujarati, Damodar. 1995-2000. “Ekonometrika Dasar”, Terjemahan: Sumarno Zain.Jakarta : Erlangga.

Gujarati, Damodar. 2004. "Basic Econometrics Fourt Edition”. New York: TheMc-Grraw Hill Companies.

Gujarati, Damodar. 2010. “Dasar-Dasar Ekonometrika”. Jakarta: Salempa Empat.

Gujarati, Damodar. 2012. “Dasar-Dasar Ekonometrika”. Jakarta: Salempa Empat.

Hapsoro, Dody Nursetyo Y. 2013. “Analisis pengaruh variabel makroekonomi regional terhadap Tingkat Kemiskinan Perkotaan (Studi Kasus 4 Kota di Indonesia Tahun 2007-2010)”. Fakultas Ekonomi dan Bisnis. Semarang: Universitas Diponegoro.

Kraay, A., 2006. When is growth pro-poor? Evidence from a panel of countries. Journal of Development Economics; 80.

Kuncoro Mudrajad. 1997. "Ekonomi Pembangunan, Teori, Masalah, dan Kebijakan, Edisi Ketiga”. Yogyakarta: UPP AMP YKPN.

Lestari, Wafi Ayu . 2011. "Pengaruh Jumlah Usaha, Nilai Investasi, dan Upah Minimum terhadap Tenaga kerja pda IKM kabupaten Semarang Jawa Tengah”. Skripsi.

Murni, Asfia.2006. "Ekonomika Makro”. Bandung: PT Refika Aditama.

Nanga, Mauna. 2005. "Makro Ekonomi Teori, masalah dan Kebijakan Edisi Pertama”. Jakarta: Rajawali Press.

Nasikun. 2001. "System Sosial Indonesia”. Bandung: Raya Grafindo Persada.

Nasir, Muhammad., Muhammad Saichudin dan Maulizar. 2008. Analisis Faktor-Faktor yang Mempengaruhi Kemiskinan Rumah Tangga di Kabupaten Purworejo. Jurnal Eksekutif, Vol. 5 No. 4, Agustus 2008. Lipi. Jakarta.

Satrio, Danie. 2010. “Analisis Dampak Investasi pada Industri Pulp dan Kertas terhadap Kesempatan Kerja dan Pendapatan Rumah Tangga Indonesia”. Semarang: Universitas Diponegoro.

Singarimbun, Masri \& Effendi, Sofian. 1989. "Metode Penelitian Survei". Jakarta: LP3ES.

Siregar, Harminto dan Wahyuniarti, Dwi. 2008. "Dampak Pertumbuhan Ekonomi Terhadap Penurunan Jumlah Penduduk Miskin". Http://Deptan.go.id

Suparmono, 2004. Pengantar Ekonomia Makro, Teori, Soal dan Penyelesaiannya, Edisi Pertama, UPP AMP YKPN, Yogyakarta.

Wardhono, A. 2004. "Mengenal Ekonometrika Teori dan Aplikasi Edisi Pertama”. Jember: Fakultas Ekonomi Universitas Jember. 